FINANCIAL: Jurnal Akuntansi

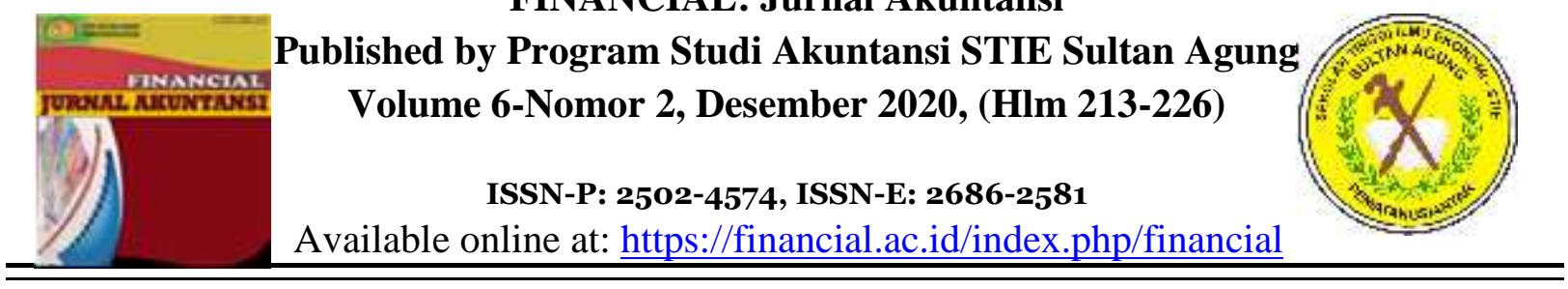

\title{
PENGUNGKAPAN TANGGUNG JAWAB SOSIAL DAN MEKANISME TATA KELOLA TERHADAP NILAI PERUSAHAAN
}

\author{
Dendi Purnama $^{1)^{*}}$, Epi Aprianti ${ }^{2)}$, Enung Nurhayati ${ }^{3)}$ \\ ${ }^{1,2,3}$ Program Studi Akuntansi, Universitas Kuningan, Jalan Cut Nyak Dhien No.36A, Cijoho, \\ Kec. Kuningan, Kabupaten Kuningan, Jawa Barat, 45513, Indonesia \\ E-mail: ${ }^{1}$ dendi.purnama@uniku.ac.id*,2epipadriano04@gmail.com, ${ }^{3}$ enung.nurhayati@uniku.ac.id
}

\begin{abstract}
Abstrak
Penelitian ini bertujuan untuk menganalisis pengaruh pengungkapan tanggung jawab sosial dan mekanisme tata kelola terhadap nilai perusahaan (studi empiris pada perusahaan sub sektor transportasi yang terdaftar di Bursa Efek Indonesia periode 2014-2018). Metode penelitian yang digunakan adalah metode deskriptif dan verifikatif. Populasi dalam penelitian ini adalah perusahaan sub sektor transportasi yang terdaftar di Bursa Efek Indonesia periode 2014-2018) sebanyak 30 perusahaan. Teknik pengambilan sampel menggunakan teknik sampel kuota dengan kriteria diperoleh sebanyak 22 perusahaan. Teknik analisis data menggunakan analisis regresi panel. Hasil temuan mengindikasikan bahwa pengungkapan tanggung jawab sosial berpengaruh positif signifikan terhadap nilai perusahaan, mekanisme tata kelola yang diproksikan oleh kepemilikan institusional, Kepemilikan manajerial Ukuran dewan komisaris, komisaris independen dan, komite audit berpengaruh positif signifikan terhadap nilai perusahaan

Kata kunci: pengungkapan tanggung jawab sosial, mekanisme tata kelola, nilai perusahaan
\end{abstract}

\section{SOCIAL RESPONSIBILITY DISCLOSURE AND GOVERNANCE MECHANISM TOWARDS CORPORATE VALUE}

\begin{abstract}
This study aims to analyze the effect of social responsibility disclosure and governance mechanisms toward firm value (empirical study of transportation sub-sector companies listed on the Indonesia Stock Exchange for the period 2014-2018). The research method used is descriptive and verification methods. The population in this study is the transportation sub-sector companies listed on the Indonesia Stock Exchange for the period 2014-2018) as many as 30 companies. The sampling technique used the quota sampling technique with the criteria obtained by 22 companies. The data analysis technique used panel regression analysis. The results of the study found that social responsibility disclosure has a significant positive effect on firm value, governance mechanisms are proxied by institutional ownership, managerial ownership, the size of the board of commissioners, independent commissioners and audit committee has a significant positive effect toward firm value.
\end{abstract}

Keywords: social responsibility disclosure, governance mechanism, corporate value

Article History: Received: 01 Des 2020 Revised: 16 Des 2020 Accepted: 18 Des 2020 


\section{PENDAHULUAN}

Nilai perusahaan menjadi salah satu indikator suatu keberhasilan manajemen perusahaan dalam mengelola perusahaan. Nilai perusahaan dapat tercermin dari kinerja perusahaan itu sendiri yang dapat mempengaruhi persepsi investor untuk menanamkan modalnya pada perusahaan. Nilai perusahaan yang tinggi dapat menjelaskan kondisi kinerja perusahaan yang baik sehingga akan membuat investor percaya dengan berekspektasi di masa yang akan dating. Cecilia et al. (2015) mengungkapkan bahwa nilai perusahaan penting bagi investor dalam menilai perusahaan karena merupakan indikator keberhasilan suatu perusahaan sehingga menjadi bahan pertimbangan bagi investor untuk berinventasi.

Pengukuran nilai perusahaan diantaranya menggunakan Price to book value (PBV) karena sangat penting bagi investor untuk menentukan strategi investasi di pasar modal. Perusahaan yang mempunyai reputasi baik pada umumnya memiliki PBV diatas satu, yang berarti bahwa nilai pasar saham lebih besar dari nilai bukunya. Semakin tinggi Nilai PBV maka semakin tinggi nilai perusahaan dimata investor (Brigham dan Houston, 2011). Berikut disajikan nilai perusahaan yang diproksikan oleh Price Book Value (PBV) pada perusahaan sub sektor Transportasi yang terdaftar di Bursa Efek Indonesia periode 2014-2018.

Tabel 1. Rata-rata PBV Perusahaan Sub Sektor Transportasi Periode 2014-2018

\begin{tabular}{|c|l|c|}
\hline No & Kode Emiten & Rata-rata PBV \\
\hline 1 & APOL & $\mathbf{- 0 , 1 5}$ \\
\hline 2 & ASSA & $\mathbf{0 , 7 2}$ \\
\hline 3 & BBRM & $\mathbf{0 , 4 8}$ \\
\hline 4 & BIRD & 3,10 \\
\hline
\end{tabular}

\begin{tabular}{|c|l|c|}
5 & BLTA & 6,32 \\
\hline 6 & BULL & $\mathbf{0 , 3 5}$ \\
\hline 7 & CANI & 18,41 \\
\hline 8 & CASS & 3,23 \\
\hline 9 & GIAA & $\mathbf{0 , 7 7}$ \\
\hline 10 & HITS & 13,84 \\
\hline 11 & IATA & $\mathbf{0 , 7 8}$ \\
\hline 12 & INDX & $\mathbf{0 , 4 9}$ \\
\hline 13 & KARW & $\mathbf{- 0 , 5 9}$ \\
\hline 14 & LEAD & $\mathbf{0 , 3 8}$ \\
\hline 15 & LRNA & $\mathbf{0 , 1 5}$ \\
\hline 16 & MBSS & $\mathbf{0 , 3 2}$ \\
\hline 17 & MIRA & $\mathbf{0 , 7 3}$ \\
\hline 18 & NELY & $\mathbf{0 , 8 0}$ \\
\hline 19 & PTIS & 1,15 \\
\hline 20 & RIGS & $\mathbf{0 , 1 2}$ \\
\hline 21 & SAFE & $\mathbf{- 1 , 8 8}$ \\
\hline 22 & SMDR & $\mathbf{0 , 3 3}$ \\
\hline 23 & SOCI & $\mathbf{0 , 7 3}$ \\
\hline 24 & TAXI & $\mathbf{0 , 6 3}$ \\
\hline 25 & TMAS & 2,39 \\
\hline 26 & TPMA & $\mathbf{0 , 8 4}$ \\
\hline 27 & TRAM & 2,33 \\
\hline 28 & WEHA & 1,08 \\
\hline 29 & WINS & $\mathbf{0 , 4 5}$ \\
\hline 30 & ZBRA & 8,68 \\
\hline SHb & Nata & \\
\hline
\end{tabular}

Sumber: data diolah dari www.idx.co.id

Dari tabel di atas terlihat bahwa beberapa perusahaan sub sektor transportasi yang terdaftar di BEI selama 5 tahun periode 2014-2018 memiliki nilai rata-rata PBV dibawah 1, yang berarti menunjukan nilai perusahaan sub sektor transportasi yang diproksikan oleh PBV dikatakan rendah, sehingga akan mempengaruhi persepsi investor dalam penilaian perusahaan karena dengan nilai PBV dibawah 1 menggambarkan harga jual perusahaan lebih rendah dibandingkan nilai buku perusahaan. Beberapa peneliti terdahulu mengungkapkan bahwa nilai perusahaan dapat dipengaruhi oleh faktor-faktor seperti profitabilitas, ukuran perusahaan, leverage, kebijakan dividen, tata kelola, 
dan tanggung jawab sosial perusahaan. Namun pada penelitian ini lebih difokuskan untuk meneliti pengungkapan tanggung jawab sosial perusahaan, serta mekanisme tata kelola perusahaan yang diproksikan oleh kepemilikan institusional, kepemilikan manajerial, ukuran dewan komisaris, komisaris independen, dan komite audit terhadap nilai perusahaan.

Penelitian berkaitan dengan pengungkapan tanggung jawab sosial perusahaan berpengaruh terhadap nilai perusahaan dilakukan oleh Agustina (2013) menjelaskan bahwa Tanggung Jawab Sosial Perusahaan berpengaruh positif signifikan terhadap nilai perusahaan, sedangkan Hasil tersebut tidak sesuai dengan hasil penelitian yang dilakukan oleh Kurniasari dan Warastuti (2015) dan Aryanto (2019) yang menemukan bahwa pengungkapan tanggung jawab sosial berpengaruh negatif dan tidak signifikan terhadap nilai perusahaan.

Selain itu, faktor lain yang dapat mempengaruhi nilai perusahaan seperti tata kelola perusahaan karena menggambarkan kondisi manajemen perusahaan dalam mengelola aset dan modalnya dengan baik. Dalam mekanisme Tata Kelola Perusahaan terdapat beberapa indikator yaitu kepemilikan institusional, kepemilikan manajerial, ukuran dewan komisaris, komisaris independen, dan komite audit. Mekanisme Tata Kelola Perusahaan ini sebagai alat pengendalian internal dalam mengawasi dan mengarahkan manajemen perusahaan untuk mewujudkan tujuan perusahaan tersebut.
Hasil penelitian Kusumaningtyas \& Andayani, (2015) menemukan bahwa kepemilikan institusional mempunyai pengaruh yang positif terhadap nilai perusahaan. Sedangkan Onasis \& Robin (2016) menemukan bahwa kepemilikan institusional berpengaruh negatif tidak signifikan terhadap nilai perusahaan.

Penelitian Sholekah \& Venusita (2014) mengungkapkan kepemilikan manajerial berpengaruh positif signifikan terhadap nilai perusahaan. Sedangkan Onasis \& Robin (2016) serta Suastini et al. (2016) menyatakan bahwa Kepemilikan Manajerial berpengaruh negatif signifikan terhadap nilai perusahaan.

Pada penelitian Marini \& Marina, (2017) mengungkapkan bahwa ukuran dewan komisaris berpengaruh positif signifikan terhadap nilai perusahaan sedangkan sedanngkan Syafitri et al. (2018) menyimpulkan bahwa terdapat hubungan yang negatif signifikan ukuran dewan komisaris dengan nilai perusahaan.

Selanjutnya Dewi \& Nugrahanti (2014) membuktikan bahwa komisaris independen berpengaruh positif signifikan terhadap nilai perusahaan. Tetapi Wardoyo (2013) dan Aryanto (2019) menemukan bahwa komisaris independen tidak berpengaruh signifikan terhadap nilai perusahaan.

Syafitri et al. (2018) dalam penelitiannya menyimpulkan bahwa Komite Audit berpengaruh positif signifikan terhadap nilai perusahaan, namun berbeda dengan hasil penelitian Muryati dan Suardhika (2014) menyatakan komite audit berpengaruh negatif signifikan terhadap nilai perusahaan. 
Dari hasil penelitian terdahulu menunjukkan adanya ketidak konsistenan hasil penelitian terdahulu sehingga penulis tertarik untuk mereplikasi penelitian mengenai pengungkapan tanggung jawab sosial perusahaan dan mekanisme tata Kelola terhadap nilai perusahaan. Namun perbedaan penelitian ini dengan penelitian terdahulu terletak pada variabel yang digunakan dimana semua proksi mekanisme tata Kelola perusahaan di uji pengaruhnya terhadap nilai perusahaan. selain itu, objek penelitian yang digunakan berbeda dengan penelitian terdahulu dimana dalam penelitian ini menggunakan perusahaan manufaktur sub sektor Transportasi yang terdaftar Di Bursa Efek Indonesia serta tahun amatan yang digunakan selama 5 tahun dari periode 2014-2018. Adapun tujuan dari penelitian ini adalah untuk menganalisis pengaruh pengungkapan tanggung jawab sosial perusahaan dan mekanisme tata Kelola terhadap nilai perusahaan (studi empiris pada perusahaan Manufaktur Sub Sektor Transportasi yang terdaftar di Bursa Efek Indonesia periode 2014-2018).

\section{LANDASAN TEORI}

\section{Teori Institusisional}

Teori Institusional menjelaskan organisasi terbentuk karena adanya tekanan lingkungan institutional yang mengakibatkan terjadi institutionalisasi. Landasan yang mendasari teori ini adalah pemikiran bahwa untuk bertahan hidup, suatu organisasi harus mampu meyakinkan kepada publik atau masyarakat bahwa organisasi adalah suatu entitas yang sah (legitimate) serta layak untuk didukung (Ridha \& Basuki, 2012). Scott et al. (2004) mengungkapkan bahwa teori institusional memfokuskan perhatian yang mendalam terhadap struktur sosial. Teori ini memfokuskan pada bagaimana struktur sepeti aturan, norma dan rutin menjadi bentuk otoritatif untuk terjadinya perilaku sosial.

\section{Tanggung Jawab Sosial Perusahaan}

Tanggung jawab sosial perusahaan merupakan suatu bentuk kepedulian perusahaan dalam upaya untuk memperbaiki kesenjangan sosial serta kerusakan lingkungan yang terjadi akibat dari aktivias operasional yang dilakukan oleh perusahaan. semakin tinggi bentuk kepedulian terhadap sosial dan lingkungan maka akan semakin meningkat citra perusahaan sehingga akan akan menjadi daya tarik bagi investor untuk berinvestasi. Dengan banyaknya investor yang tertarik akan meningkatkan nilai perusahaan. Semakin luas pengungkapan tanggung jawab sosial semakin baik nilai perusahaan. Aryanto (2019) dan Agustina (2013) menjelaskan bahwa Pengungkapan tanggung jawab sosial perusahaan berpengaruh positif terhadap nilai perusahaan. Maka hipotesis yang diajukan sebagai berikut:

\section{$\mathrm{H}_{1}$ : Pengungkapan tanggung jawab sosial perusahaan berpengaruh positif terhadap nilai perusahaan}

\section{Kepemilikan Institusional}

Kepemilikan institusional sebagai bentuk kepemilikan saham dari berbagai institusi, seperti pemerintah, perusahaan asuransi atau Lembaga keuangan, dan lainnya. Semakin tinggi tingkat kepemilikan saham yang dimiliki institusi dalam perusahaan, akan meningkatkan pengawasan yang lebih optimal terhadap kinerja perusahaan hal ini akan berdampak pada nilai perusahaan. Dengan adanya 
kepemilikan institusional akan dapat memonitor tim manajemen secara efektif dan dapat meningkatkan nilai perusahaan. Kusumaningtyas \& Andayani, (2015) mengungkapkan kepemilikan institusional berpengaruh positif terhadap nilai perusahaan. Maka hipotesis yang diajukan sebagai berikut:

$\mathrm{H}_{2}$ : Kepemilikan institusional berpengaruh positif terhadap nilai perusahaan

\section{Kepemilikan Manajerial}

Menurut Sholekah \& Venusita (2014) kepemilikan manajerial merupakan presentase kepemilikan saham yang dimiliki oleh direksi, manajer, dan dewan komisaris. Adanya kepemilikan saham ini, manajerial akan bertindak hati-hati dalam mengambil keputusan karena turut menanggung konsekuensi atas keputusan yang diambil. Pihak manajemen perusahaan juga akan termotivasi dalam meningkatkan kinerja perusahaannya. Semakin tinggi porsi saham yang dimiliki oleh manajemen perusahaan maka semakin tinggi nilai perusahan. Sholekah \& Venusita (2014) yang menyatakan bahwa Kepemilikan Manajerial berpengaruh positif terhadap nilai perusahaan. Maka hipotesis yang diajukan sebagai berikut:

$\mathrm{H}_{3}$ : Kepemilikan institusional berpengaruh positif terhadap nilai perusahaan

\section{Ukuran Dewan Komisaris}

Dewan komisaris mempunyai peran yang sangat penting dalam keberhasilan suatu perusahaan. Dengan adanya Dewan komisaris dapat mengarahkan dan mengawasi manajemen perusahaan dalam mengelola perusahaan dengan tujuan agar mewujudkan tata Kelola perusahaan yang baik. Keberhasilan perusahaan dalam mewujudkan kinerja perusahaan yang baik akan berdampak pada citra perusahaan yang baik. Dengan demikian dapat menarik investor untuk berinvestasi pada perusahaan tersebut. Dengan banyaknya investor yang tertarik akan meningkatkan harga saham dan secara tidak langsung akan meningkatkan nilai perusahaan. Dalam hal ini semakin besar ukuran dewan komisaris maka semakin baik kinerja perusahaan sehingga semakin tinggi nilai perusahaan. Marini \& Marina, (2017) menemukan bahwa ukuran dewan komisaris berpengaruh positif terhadap nilai perusahaan. Maka hipotesis yang diajukan sebagai berikut

$\mathrm{H}_{4}$ : Ukuran dewan komisaris berpengaruh positif terhadap nilai perusahaan

\section{Komisaris Independen}

Komisaris independen mempunyai peran dalam mengawasi manajemen perusahaan agar perusahaan menjalankan tata Kelola yang baik untuk mencapai tujuan dan keberlangsung perusahaan. Semakin baik peran komisaris independen maka semakin baik kinerja perusahaan. Dengan kinerja yang baik maka akan berdampak harga saham dan banyak investor yang berminat sehingga nilai perusahaan akan meningkat. Onasis \& Robin (2016) mengatakan bahwa komisaris independen berpengaruh positif signifikan terhadap nilai perusahaan. Maka hipotesis yang diajukan sebagai berikut:

$\mathrm{H}_{5}$ : Komisaris Independen berpengaruh positif terhadap nilai perusahaan

\section{Komite Audit}

Komite audit mempunyai tugas dalam mengawasi manajemen perusahaan. Komite audit dapat memantau sistem 
pengendalian internal yang dijalankan oleh perusahaan. Tujuannya agar manajemen perusahaan tidak semena-mena dalam menjalankan wewenangnya dan mementingkan kepentingan sendiri. Dengan adanya komite audit dapat meminimalisir terjadinya asimetri informasi sehingga perusahaan dapat berjalan secara efektif dan efisien. Hal ini berarti bahwa semakin baik peran komite audit dalam pengawasan maka semakin baik kinerja perusaahan. Dengan semakin baik kinerja perusahaan akan menjadi sorotan bagi investor sehingga tertarik untuk membeli saham perusahaan. Dengan banyaknya investor yang berminat maka semakin tinggi nilai perusahaan. Syafitri et al. (2018) mengungkapkan bahwa komite audit berpengaruh positif terhadap nilai perusahaan.

\section{METODE}

Metode yang digunakan dalam Penelitian yaitu metode deskriptif dan verifikatif dengan pendekatan Kuantitatif. Populasi penelitian ini adalah seluruh perusahaan sub sektor transportasi yang terdaftar di Bursa Efek Indonesia periode 2014-2018 sebanyak 30 perusahaan. Teknik penentuan sampel menggunakan Teknik kuota sampling. Adapun kriteria penentuan sampel sebagai berikut:

Tabel 2. Kriteria Penentuan Sampel

\begin{tabular}{|c|lr|c|}
\hline No & \multicolumn{1}{|c|}{ Kriteria } & Jumlah \\
\hline 1 & $\begin{array}{l}\text { Perusahaan sub sektor } \\
\text { Transfortasi } \\
\text { terdaftar di dalam Bursa }\end{array}$ & 30 \\
& $\begin{array}{l}\text { Efek Indonesia periode } \\
\text { 2014-2018. }\end{array}$ & \\
\hline 2 & $\begin{array}{l}\text { Perusahaan sub sektor } \\
\text { transfortasi yang tidak } \\
\text { mempublikasikan }\end{array}$ & \\
& $\begin{array}{l}\text { laporan tahunan secara } \\
\text { lengkap pada periode }\end{array}$ & \\
\hline
\end{tabular}

\begin{tabular}{|c|l|c|}
\hline 3 & $\begin{array}{l}\text { tahun 2014-2018 } \\
\text { Perusahaan tersebut } \\
\text { tidak mengungkapkan } \\
\text { laporan tanggung jawab } \\
\text { sosial perusahaan secara } \\
\text { lengkap tahun 2014- } \\
2018\end{array}$ & \\
\hline & $\begin{array}{l}\text { Jumlah perusahaan yang } \\
\text { menjadi sampel }\end{array}$ & 22 \\
\hline & $\begin{array}{l}\text { Tahun Penelitian 2014- } \\
\text { 2018 }\end{array}$ & 5 \\
\hline & $\begin{array}{l}\text { Jumlah Observasi } \\
\text { Penelitian }\end{array}$ & 110 \\
\hline
\end{tabular}

Berikut ini nama-nama perusahaan yang menjadi sampel dalam penelitian ini:

Tabel 3. Sampel Penelitian

\begin{tabular}{|l|l|}
\hline No & \multicolumn{1}{|c|}{ Nama Perusahaan } \\
\hline 1 & Adi Sarana Armada Tbk \\
\hline 2 & $\begin{array}{l}\text { Pelayaran Nasional Bina Buaya } \\
\text { Raya Tbk }\end{array}$ \\
\hline 3 & Blue Bird Tbk \\
\hline 4 & Berlian Laju Tanker Tbk \\
\hline 5 & Buana Lintas Lautan Tbk \\
\hline 6 & Cardig Aegro Services Tbk \\
\hline 7 & Garuda Indonesia (Persero) Tbk \\
\hline 8 & Tanah Laut Tbk \\
\hline 9 & ICTSI Jasa Prima Tbk \\
\hline 10 & Logindo Samudramakmur Tbk \\
\hline 11 & Eka Sari Lorena Transport Tbk \\
\hline 12 & Mitrabahtera Segara Sejati Tbk \\
\hline 13 & Pelayaran Nelly Dwi Putri Tbk \\
\hline 14 & Indo Straits Tbk \\
\hline 15 & Rig Tenders Indonesia Tbk \\
\hline 16 & Steady Safe Tbk \\
\hline 17 & Samudera Indonesia Tbk \\
\hline 18 & Soechi Lines Tbk \\
\hline 19 & Pelayaran Tempuran Emas Tbk \\
\hline 20 & Trans Power Marine Tbk \\
\hline 21 & WEHA Transportasi Indonesia \\
\hline 22 & Tbk \\
\hline Wintermar Offshore Marine Tbk \\
\hline
\end{tabular}

Sumber Bursa Efek Indonesia 
Tabel 4. Operasional Variabel

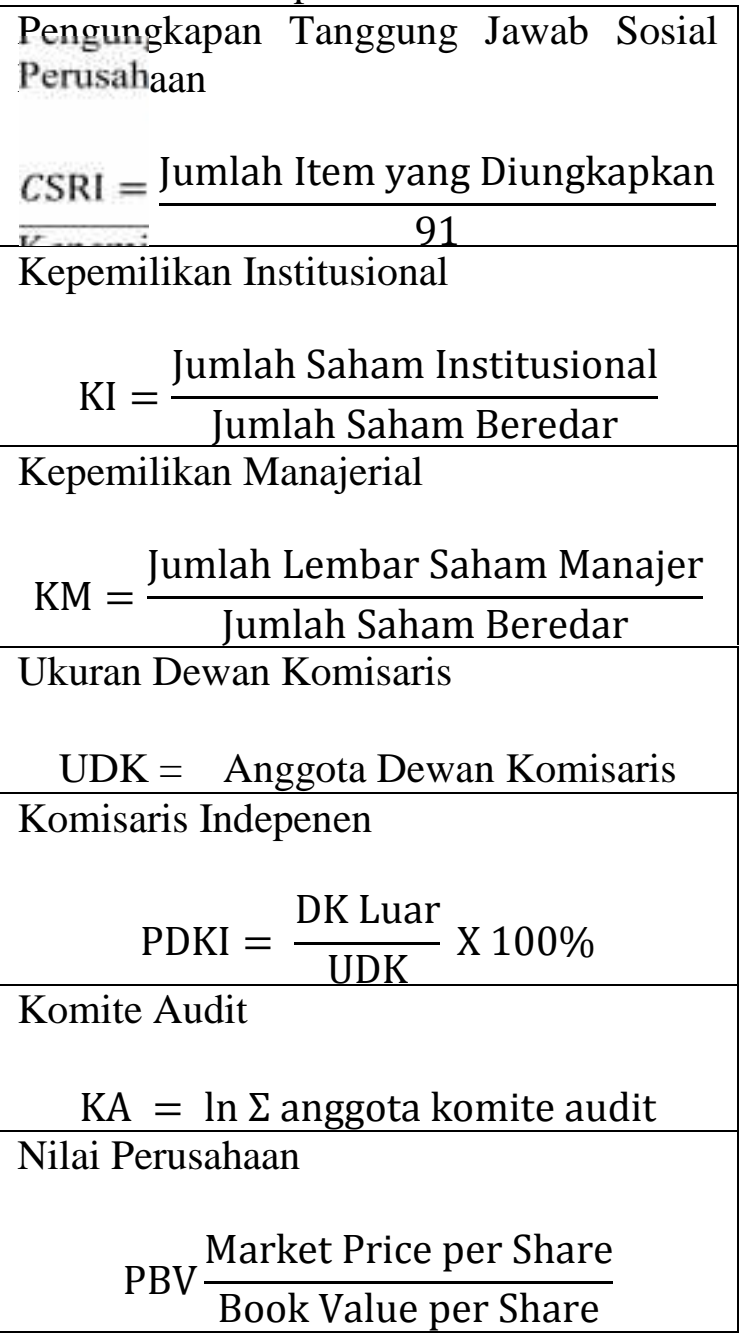

Sumber: (Dewi \& Nugrahanti, 2014)

Jenis data yang digunakan adalah data sekunder berupa laporan tahunan perusahaan sub sektor transportasi periode 2014-2018 yang diperoleh dari website www.idx.co.id. Teknik analisis data menggunakan analisis deskriptif dan analisis verifikatif meliputi uji asumsi klasik.

\section{HASIL DAN PEMBAHASAN}

Analisis Deskriptif

Tabel 5. Analisis Deskriptif

\begin{tabular}{|l|c|c|c|}
\hline Variabel & Mean & Maks & Min \\
\hline PTS & 0,08 & 0,21 & 0,01 \\
\hline KI & 0,66 & 0,97 & 0,03 \\
\hline
\end{tabular}

Copyright (C) 2020, FINANCIAL: Jurnal Akuntansi

\begin{tabular}{|l|c|c|c|}
\hline KM & 0,08 & 0,58 & 0,00 \\
\hline UDK & 3,67 & 8,00 & 2,00 \\
\hline KI & 39,11 & 66,67 & 20,00 \\
\hline KA & 3,04 & 5,00 & 2,00 \\
\hline
\end{tabular}

Sumber: output eviews

Dari data di atas terlihat bahwa nilai rata-rata Tanggung Jawab Sosial Perusahaan dari 22 Perusahaan Transportasi tahun 2014-2018 adalah sebesar 0,08. Nilai Maximum adalah 0,21. Terdapat pada perusahaan ASSA pada tahun 2018. Nilai Minimum sebesar 0,011 terdapat pada perusahaan INDX pada tahun 2018 dan WINS pada tahun 2014.

Dari data di atas terlihat bahwa nilai rata-rata kepemilikan institusional dari 22 Perusahaan sub sektor Transportasi tahun 2014-2018 adalah sebesar 0,66. Nilai Maximum adalah 0.97. Terdapat pada perusahaan TPMA pada tahun 2018. Nilai Minimum sebesar 0,03. terdapat pada perusahaan SMDR pada tahun 2018.

Dari data di atas terlihat bahwa nilai rata-rata kepemilikan manajerial dari 22 Perusahaan Transportasi tahun 2014-2018 adalah sebesar 0,08. Nilai Maximum adalah 0,58. Terdapat pada perusahaan WEHA pada tahun 2014. Nilai Minimum sebesar 0,00. terdapat pada perusahaan BULL KARW LRNA MBSS RIGS.

Dari data di atas terlihat bahwa nilai rata-rata ukuran dewan komisaris dari 22 Perusahaan Transportasi tahun 2014-2018 adalah sebesar 3,67. Nilai Maximum adalah 8. Terdapat pada perusahaan BIRD. Nilai Minimum sebesar 2. terdapat pada perusahaan INDX, SAFE dan WEHA.

Dari data di atas terlihat bahwa nilai rata-rata komisari independen dari 22 Perusahaan Transportasi tahun 2014-2018 adalah sebesar 39,10\%. Nilai Maximum 
adalah $66,67 \%$. Terdapat pada perusahaan BULL. Nilai Minimum sebesar $20 \%$.

Dari data di atas terlihat bahwa nilai rata-rata komite audit dari 22 Perusahaan Transportasi tahun 2014-2018 adalah sebesar 3,03. Nilai Maximum adalah 5 Terdapat pada perusahaan MBSS pada tahun 2018. Nilai Minimum sebesar 2. terdapat pada perusahaan NELY pada tahun 2018.

\section{Analisis Verifikatif}

\section{Uji Normalitas}

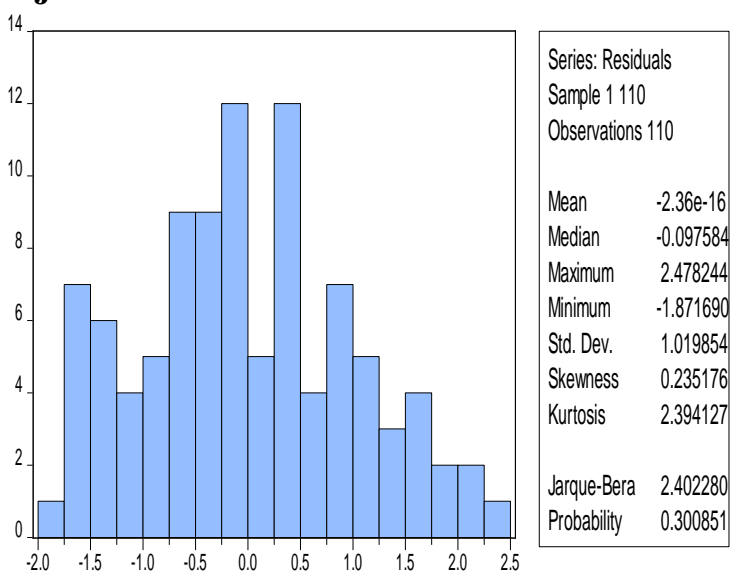

Sumber: output eviews

Gambar 1. Uji Normalitas

Dari gambar di atas dapat dilihat hasil uji normalitas menunjukan nilai probability atau p-value adalah $0.301>$ 0,05 maka $\mathrm{H}_{0}$ diterima dan dapat disimpulkan bahwa data yang digunakan berdistribusi normal.

\section{Uji Multikolinieritas}

Tabel 6. Uji Multikolinieritas

\begin{tabular}{llll}
\hline & Variance & VIF & VIF \\
C & 0.716941 & 21.08901 & NA \\
PTS & 20.05878 & 5.182644 & 1.372019 \\
KI & 0.882614 & 12.54210 & 1.342316 \\
KM & 2.701889 & 2.094033 & 1.563901 \\
UDK & 0.022708 & 10.46899 & 1.458725 \\
KI & $3.43 E-11$ & 1.019054 & 1.009551 \\
KA & 0.158532 & 7.433548 & 1.373647 \\
\hline
\end{tabular}

Sumber: output eviews
Berdasarkan tabel di atas diperoleh bahwa semua variabel independen nilai VIF $<10$ artinya bahwa Tidak Terjadi Multikolinieritas dalam Model Regresi.

\section{Uji Heterokedastisitas}

Tabel 7. Uji Heteroskedastisitas

Heteroskedasticity Test: BreuschPagan-Godfrey

\begin{tabular}{|c|c|c|}
\hline & & $\begin{array}{l}\text { Prob. } \\
\text { F(6.91) }\end{array}$ \\
\hline abs* & & $\begin{array}{l}F(0,91) \\
\text { Prob. Chi- } \\
\text { Square(6) }\end{array}$ \\
\hline
\end{tabular}

Sumber: Output Eviews

Berdasarkan tabel diatas, p-value $O b s * R$-Square sebesar $0.3746>0,05$, maka $\mathrm{H}_{0}$ diterima. Artinya dalam penelitian ini tidak terdapat heteroskedastisitas.

\section{Uji Autokorelasi}

Tabel 8. Uji Autokorelasi

\begin{tabular}{llll}
\hline $\begin{array}{l}\text { F- } \\
\text { statistic }\end{array}$ & 4.3918 & $\begin{array}{l}\text { Durbin- } \\
\text { Watson }\end{array}$ & $\mathbf{1 . 8 8 7 7}$ \\
\hline
\end{tabular}

Sumber: output eviews

Berdasarkan tabel diatas, diketahui bahwa nilai Durbin-Watsoon sebesar 1.8877 maka berdasarkan kriteria hipotesis tidak terdapat Autokorelasi harus $\mathrm{d}_{\mathrm{L}}<\mathrm{dw}$ $<4-\mathrm{d}_{\mathrm{U}}$. Dimana $\mathrm{dw}=1.887726, \mathrm{~d}_{\mathrm{L}}=$ 1,5761 dan $\mathrm{d}_{U}=1,8054\left(4-\mathrm{d}_{\mathrm{U}}=4-1,8054\right.$ $=2.1946)$, sehingga dengan rumus $d_{L}<d w$ $<4-\mathrm{d}_{\mathrm{U}}$ maka $1,5761<1.8877<2.1946$ artinya tidak terdapat autokorelasi.

\section{Regresi Data Panel}

Berdasarkan hasil estimasi ketiga model bahwa model mengikuti Fixed Effect. Maka dari hasil estimasi dengan menggunakan model Fixed Effect dapat dibentuk persamaan sebagai berikut: 
Tabel 9. Analisis Regresi Data Panel

\begin{tabular}{lcc}
\hline Variable & Coefficient & t-Statistic \\
$\mathrm{C}$ & 0.451900 & 3.4188 \\
$\mathrm{CSR}$ & 0.541207 & 6.9298 \\
$\mathrm{KI}$ & 0.685862 & 3.0796 \\
$\mathrm{KM}$ & 0.589478 & 2.6352 \\
$\mathrm{UDK}$ & 0.651781 & 7.9678 \\
KOI & 0.914600 & 20.658 \\
KOA & 0.596769 & 8.9486 \\
\hline
\end{tabular}

Sumber: output eviews

$\begin{array}{llll}\mathrm{Y}_{\mathrm{it}}=0.451900 & +0.228143_{\mathrm{ASSA}} & - \\ 0.910277_{\mathrm{BBRM}} & - & 0.158718_{\mathrm{BIRD}} & + \\ 0.185923_{\mathrm{BLTA}} & + & 0.119539_{\mathrm{BULL}} & + \\ 1.340358_{\mathrm{CASS}} & - & 0.954333_{\mathrm{GIAA}} & + \\ 0.077202_{\mathrm{INDX}} & - & 0.146769_{\mathrm{KARW}} & - \\ 0.530053_{\mathrm{LEAD}} & - & 0.241634_{\mathrm{LRNA}} & - \\ 0.509219_{\mathrm{MBSS}} & - & 0.186306_{\mathrm{NELLY}} & - \\ 0.137455_{\mathrm{PTIS}} & - & 0.315612_{\mathrm{RIGS}} & + \\ 0.188651_{\mathrm{SAFE}} & + & 0.203553_{\mathrm{SMDR}} & + \\ 0.435008_{\mathrm{SOCI}} & + & 0.697582_{\mathrm{TMAS}} & + \\ 0.329063_{\mathrm{TPMA}}+ & + & 0.121762_{\mathrm{WEHA}} & + \\ 0.163593_{\mathrm{WINS}}+ & + & 0.541207 \mathrm{X}_{\mathrm{CSR}} & + \\ 0.685862 \mathrm{X}_{\mathrm{KI}} & + & 0.589478 \mathrm{X}_{\mathrm{KM}} & + \\ 0.651781 \mathrm{X}_{\mathrm{UDK}}+ & { }^{+} & + \\ 0.596769 \mathrm{X}_{\mathrm{KOA}} & €_{\mathrm{it}} & & \end{array}$

Koefisien Determinasi

Tabel 10. Hasil Uji Koefisien Determinasi

\begin{tabular}{ll}
\hline R-squared & 0.97296 \\
\hline Adjusted R-squared & $\mathbf{0 . 9 6 4 0 5}$ \\
\hline
\end{tabular}

Sumber: output eviews

Berdasarkan pada tabel diatas, didapat dilihat nilai adjusted $R$ Square adalah 0,96405 . Nilai ini berarti bahwa sebesar $96,40 \%$ perubahan variabel dependen dapat dijelaskan oleh variabel penentu dalam model, sedangkan sisanya $3.6 \%$ dipengaruhi oleh variabel lain di luar model.

Copyright (C) 2020, FINANCIAL: Jurnal Akuntansi

\section{Uji Kelayakan Model}

Tabel 11. Hasil Uji Kelayakan Model

\begin{tabular}{ll}
\hline F-statistic & 109.26 \\
\hline Prob(F-statistic) & 0.0000 \\
\hline
\end{tabular}

Sumber: Output Eviews

Dari data di atas terlihat bahwa nilai F hitung sebesar 109,26 dengan tingkat signifikansi 0,0000. Dengan menggunakan tingkat $\alpha(0,05)$ atau 5\%, maka $\mathrm{Ha}$ diterima. Penerimaan $\mathrm{Ha}$ dibuktikan dengan hasil perhitungan bahwa nilai $F_{\text {hitung }}>F_{\text {tabel(0,05) }}(109,26>2,19)$, maka model layak digunakan sehingga dapat disimpulkan bahwa pengungkapan tanggung jawab sosial dan tata kelola berpengaruh signifikan secara simultan terhadap nilai perusahaan.

\section{Uji Hipotesis}

Tabel 12. Hasil Uji Hipotesis

\begin{tabular}{lcc} 
Variable & t-Statistic & Prob. \\
C & 3.4188 & 0.001 \\
CSR & 6.9298 & 0.000 \\
KI & 3.0796 & 0.003 \\
KM & 2.6352 & 0.010 \\
UDK & 7.9678 & 0.000 \\
KOI & 20.6583 & 0.000 \\
KOA & 8.9486 & 0.000 \\
\hline
\end{tabular}

Sumber: output eviews

Hasil uji hipotesis pertama diperoleh nilai $t_{\text {hitung }}>t_{\text {tabel }}(6,9298>$ $1,6595)$ dengan nilai probabilitas $0,0000<$ 0,05 artinya $\mathrm{H}_{0}$ ditolak dan $\mathrm{H}_{\mathrm{a}}$ diterima. Dengan demikian pengungkapan tanggung jawab sosial secara parsial berpengaruh positif signifikan terhadap nilai perusahaan.

Hasil uji hipotesis kedua diperoleh nilai $t_{\text {hitung }}>t_{\text {tabel }}(3,0796>1,6595)$ dengan nilai probabilitas $0,0003<0,05$ artinya $\mathrm{H}_{0}$ ditolak dan $\mathrm{H}_{\mathrm{a}}$ diterima. Dengan demikian kepemilikan institusional secara parsial 
berpengaruh positif signifikan terhadap nilai perusahaan.

Hasil uji hipotesis ketiga diperoleh nilai $t_{\text {hitung }}>t_{\text {tabel }}(2,6352>1,6595)$ dengan nilai probabilitas $0,010<0,05$ artinya $\mathrm{H}_{0}$ ditolak dan $\mathrm{H}_{\mathrm{a}}$ diterima. Dengan demikian kepemilikan manajerial secara parsial berpengaruh positif signifikan terhadap nilai perusahaan.

Hasil uji hipotesis keempat diperoleh nilai $t_{\text {hitung }}>t_{\text {tabel }}(7,9678>$ $1,6595)$ dengan nilai probabilitas $0,0000<$ 0,05 artinya $\mathrm{H}_{0}$ ditolak dan $\mathrm{H}_{\mathrm{a}}$ diterima. Dengan demikian ukuran dewan komisaris secara parsial berpengaruh positif signifikan terhadap nilai perusahaan.

Hasil uji hipotesis kelima diperoleh nilai $t_{\text {hitung }}>t_{\text {tabel }}(20,658>1,6595)$ dengan nilai probabilitas $0,0000<0,05$ artinya $\mathrm{H}_{0}$ ditolak dan $\mathrm{H}_{\mathrm{a}}$ diterima. Dengan demikian komisaris independen secara parsial berpengaruh positif signifikan terhadap nilai perusahaan.

Hasil uji hipotesis keenam diperoleh nilai $t_{\text {hitung }}>t_{\text {tabel }}(8,9486>$ 1,6595) dengan nilai probabilitas $0,0000<$ 0,05 artinya $\mathrm{H}_{0}$ ditolak dan $\mathrm{H}_{\mathrm{a}}$ diterima. Dengan demikian komite audit secara parsial berpengaruh positif signifikan terhadap nilai perusahaan.

\section{Pembahasan}

\section{Pengungkapan Tanggung Jawab Sosial terhadap Nilai Perusahaan}

Hasil pengujian hipotesis menunjukkan bahwa pengungkapan tanggung jawab sosial secara parsial berpengaruh positif signifikan terhadap nilai perusahaan. Hal ini berarti bahwa semakin luas pengungkapan tanggung jawab sosial perusahaan, maka semakin tinggi nilai perusahaan. Tanggung jawab perusahaan tidak hanya mengungkapkan

informasi yang wajib seperti laporan keuangan namun juga harus mengungkapkan informasi sukarela mengenai laporan tanggung jawab sosial. Hal ini menjadi bukti bahwa perusahaan peduli terhadap sosial dan lingkungan sebagai upaya dalam memenuhi kewajiban sebagai entitas yang harus melakukan tanggung jawab sosial. Dengan demikian, Ketika citra perusahaan baik karena kepedulian terhadap sosial dan lingkungan tinggi, maka nilai perusahaan tersebut akan dipandang tinggi. Hasil penelitian ini didukung oleh penelitian yang dilakukan oleh Arisanti et al. (2013) dan Ratnadewi \& Ulupui, (2016) menemukan bahwa pengungkapan tanggung jawab sosial perusahaan memiliki pengaruh positif signifikan terhadap nilai perusahaan.

\section{Kepemilikan Institusional terhadap Nilai Perusahaan}

Hasil pengujian $\begin{array}{r}\text { hipotesis } \\ \text { bepemilikan }\end{array}$
institusional secara parsial berpengaruh
positif signifikan terhadap nilai
perusahaan. Hal ini berarti bahwa semakin
besar kepemilikan saham oleh pihak
institusi maka semakin tinggi nilai
perusahaan. Tingkat kepemilikan institusi
yang tinggi dapat mengendalikan
perusahaan sehingga akan lebih ketat
dalam pengawasan terhadap manajemen
perusahaan. Keberadaan pihak institusi
dianggap mampu menjadi mekanisme
monitoring yang efektif agar manajemen
perusahaan menjalankan tata Kelola
perusahaan dengan baik dengan tujuan
agar untuk menciptakan kinerja
perusahaan yang baik. Dengan kinerja
perusahaan yang baik akan menjadi
sorotan bagi investor sehingga nilai
perusahaan dipandang tinggi. Hasil


penelitian ini didukung oleh hasil penelitian terdahulu P.D \& Suartana (2014) Lin and Fu (2017); Widianingsih (2018) menyatakan bahwa kepemilikan institusional berpengaruh positif terhadap nilai perusahaan.

\section{Kepemilikan Manajerial terhadap Nilai} Perusahaan

$\begin{array}{ccr}\text { Hasil } & \text { pengujian } & \text { hipotesis } \\ \text { menemukan } & \text { bahwa } & \text { kepemilikan } \\ \text { manajerial } & \text { secara parsial } & \text { berpengaruh }\end{array}$
positif signifikan terhadap nilai perusahaan. Hal ini berarti bahwa Semakin tinggi proporsi kepemilikan saham oleh manajemen perusahaan maka semakin tinggi nilai perusahaan. Dewan direksi maupun manajer perusahaan akan meningkatkan tata Kelola perusahaan untuk mewujudkan kinerja perusahaan yang lebih baik. Dengan kinerja yang baik banyak investor yang akan tertarik untuk berinvestasi sehingga harga saham perusahaan meningkat dan berdampak pada nilai perusahaan. Hasil penelitian ini didukung oleh penelitian terdahulu Jusriani \& Rahardjo (2013) bahwa kebijakan manajerial berpengaruh positif dan signifikan terhadap nilai perusahaan.

\section{Ukuran Dewan Komisaris terhadap Nilai Perusahaan}

Hasil pengujian hipotesis menemukan bahwa ukuran dewan komisaris secara parsial berpengaruh positif signifikan terhadap nilai perusahaan. Hal ini berarti bahwa semakin besar ukuran dewan komisaris, maka semakin tinggi nilai perusahaan. Dewan komisaris mempunyai peran dalam mengawasi dan memberi arahan terhadap manajemen perusahaan. Tujuannya adalah untuk mewujudkan tata Kelola yang baik dan untuk mencapai tujuan perusahaan serta keberlangsungan perusahaan. Ketika perusahaan menerapkan tata Kelola yang baik diharapkan meningkatkan efektivitas dan efisiensi aktivitas perusahaan. Hal ini akan berdampak pada kinerja perusahaan. Dengan kinerja perusahaan yang baik maka manajemen perusahaan telah berhasil mengelola asset dengan baik. Dengan demikian, para investor akan berlomba-lomba untuk berinvestasi dan berdampak pada nilai perusaahan yang tinggi. Hasil penelitian ini sejalan dengan hasil penelitian Ahmad et al., (2020) yang menyatakan bahwa ukuran dewan komisaris berpengaruh positif siginifikan terhadap Nilai Perusahaan.

\section{Komisaris Independen}

Berdasarkan hasil pengujian hipotesis menemukan bahwa komisaris independen secara parsial berpengaruh positif signifikan terhadap nilai perusahaan. Hal ini berarti bahwa semakin banyak komisaris independen semakin tinggi nilai perusahaan. Komisaris independen dapat menjadi alat monitoring bagi manajemen perusahaan agar menjalankan perusahaan sesuai dengan tata Kelola perusahaan yang baik. Komisaris independen merupakan harapan bagi investor untuk mengawasi kinerja perusahaan. Ketika kinerja perusahaan baik maka peran komisaris independen telah berhasil dalam mengarahkan perusahaan. Hal ini akan memberikan kepercayaan kepada investor mengenai kinerja perusahaan tersebut. Dengan kinerja yang baik maka dapat berdampak pada nilai perusahaan. Hasil ini sejalan dengan penelitian Onasis \& Robin (2016) 
yang menyimpulkan bahwa dewan komisaris independen berpengaruh positif terhadap nilai perusahaan.

\section{Komite Audit Terhadap Nilai Perusahaan}

Hasil pengujian hipotesis menemukan bahwa komite audit secara parsial berpengaruh positif signifikan terhadap nilai perusahaan. Hal ini berarti bahwa semakin baik fungsi komite audit maka semakin tinggi nilai perusahaan. Komite audit memiliki fungsi dalam mengawasi dan mengontrol manajemen perusahaan dengan tujuan untuk mewujudkan tata Kelola yang baik. Komite audit dapat mengarahkan manajemen perusahaan agar menghasilkan laporan keuangan yang berkualitas. Selain itu, komite audit dapat memonitor sistem pengendalian internal perusahaan agar manajemen perusahaan berprilaku tidak etis. Dengan adanya komite audit dapat mewujudkan kinerja perusahaan yang lebih baik sehingga akan berdampak pada nilai perusahaan. Hasil penelitian ini sejalan dengan hasil penelitian Onasis \& Robin (2016), Gill \& Obradovich (2012) dan Aryanto (2019) yang menyatakan bahwa komite audit memiliki pengaruh positif signifikan terhadap Nilai Perusahaan.

\section{SIMPULAN DAN SARAN}

Hasil temuan menyimpulkan bahwa pengungkapan tanggung jawab sosial dan mekanisme tata Kelola yang diproksikan dengan Kepemilikan Institusional, Kepemilikan Manajerial, Ukuran Dewan Komisaris, Komisaris Independen, dan Komite Audit berpengaruh positif signifikan terhadap nilai perusahaan. Pengungkapkan tanggung jawab sosial perusahaan dapat meningkatkan citra perusahaan karena kepedulian terhadap sosial dan lingkungan sehingga dapat meningkatkan nilai perusahaan. Mekanisme tata Kelola perusahaan transportasi telah berperan dengan baik sebagai alat monitoring bagi perusahaan agar kinerja perusahaan semakin baik sehingga dapat berdampak terhadap nilai perusahaan.

Dari hasil simpulan yang telah dijabarkan maka saran yang dapat diberikan penulis adalah untuk meningkatkan nilai perusahaan, agar terus meningkatkan kepedulian terhadap sosial dan lingkungan sebagai upaya dalam mempromosikan keberadaan perusahaan serta produk terhadap masyarakat luas sehingga nama baik perusahaan akan meningkat dengan demikian nilai perusahaan akan meningkat. Untuk meningkatkan nilai perusahaan, perusahaan harus terus mengoptimalkan mekanisme tata Kelola menjadi lebih baik dalam pengawasan sehingga pengelolaan perusahaan akan dijalankan dengan baik. Hal ini akan mendorong manajemen perusahaan untuk meningkatkan kinerja perusahaan sehingga akan berdampak terhadap nilai perusahaan. Selain itu, untuk penelitian selanjutnya agar dapat menambah variabel dan memperbanyak tahun amatan.

\section{DAFTAR PUSTAKA}

Agustina, S. (2013). Pengaruh Profitabilitas dan Pengungkapan Corporate Sosial Responsibility terhadap Nilai Perusahaan. Artikel Ilmiah.

Ahmad, G. N., Lullah, R., \& Siregar, M. E. S. (2020). Pengaruh Keputusan Investasi, Keputusan Pendanaan, Kebijakan Dividen, dan Ukuran Dewan Komisaris terhadap Nilai Perusahaan pada Perusahaan 
Manufaktur yang Terdaftar Di Bursa Efek Indonesia Periode 2016-2018. Jurnal Riset Manajemen Sains Indoensia, 11(1).

Arisanti, I., Fadah, I., \& Puspitarasi, N. (2013). Analisis Faktor Keuangan Dan Non Keuangan Yang Mempengaruhi Prediksi Peringkat Obligasi Syariah (Studi Empiris Pada Perusahaan Penerbit Obligasi Syariah Yang Terdaftar Di Bursa Efek Indonesia Periode 2010-2012). Jurnal Ilmiah Prodi Manajemen Universitas Jember, 1-13.

Aryanto, A. (2019). Pengaruh Tata Kelola Perusahaan Dan Tanggung Jawab Sosial Terhadap Nilai Perusahaan Sektor Pertambangan. Jurnal Informasi, Perpajakan, Akuntansi, Dan Keuangan Publik, 14(2), 181. https://doi.org/10.25105/jipak.v14i2.5 020

Cecilia, Rambe, S., \& Torong, M. Z. B. (2015). Analisis Pengaruh Corporate Social Responsibility, Profitabilitas dan Ukuran Perusahaan Terhadap Nilai Perusahaan yang Go Public di Indonesia, Malaysia, dan Singapura. Simposium Nasional Akuntansi, Hal 1-22.

Dewi, L. C., \& Nugrahanti, Y. W. (2014). Pengaruh Struktur Kepemilikan Dan Dewan Komisaris Independen Terhadap Nilai Perusahaan (Studi Pada Perusahaan Industri Barang Konsumsi Di Bei Tahun 2011-2013). Kinerja, $\quad 18(1), \quad 64$. https://doi.org/10.24002/kinerja.v18i1 .518

Gill, A., \& Obradovich, J. (2012). The Impact of Corporate Governance and Financial Leverage on the Value of American firms. International Research Journal of Finance and Economics, 91(September), 46-56.

Jusriani, I. F., \& Rahardjo, S. N. (2013). Analisis Pengaruh Profitabilitas, Kebijakan Deviden, Kebijakan Utang,
Dan Kepemilikan Manajerial Terhadap Nilai Perusahaan (Studi Empiris Pada Perusahaan Manufaktur Yang Terdaftar Di Bursa Efek Indonesia Periode 2009 2011). Diponegoro Journal of Accounting, 2(2), 1-10.

Kusumaningtyas, T. K., \& Andayani. (2015). Pengaruh Good Corporate Governance terhadap Nilai Perusahaan yang Terdaftar Pada Indeks SRI-KEHATI. Jurnal Ilmu \& Riset Akuntansi, 4(7), 1-16.

Marini, Y., \& Marina, N. (2017). Pengaruh Good Corporate Governance Terhadap Nilai Perusahaan. Jurnal Humaniora, 1(1).

Onasis, K., \& Robin. (2016). Pengaruh Tata Kelola Perusahaan terhadap Nilai Perusahaan pada Perusahaan Sektor Keuangan yang Terdaftar di BEI. Bina Ekonomi, 20(1), 1-22. https://doi.org/10.26593/be.v20i1.189 3.1-22

P.D, N. P. W., \& Suartana, I. W. (2014). Pengaruh Kepemilikan Manajerial dan Kepemilikan Institusional Pada Nilai Perusahaan. E-Jurnal Akuntansi Universitas Udayana, 9(3), 575-590.

Peraturan Pemerintah Republik Indonesia, N. 47 T. 2012. (n.d.). Tanggung Jawab Sosial dan Lingkungan Perseroan Terbatas.

Ratnadewi, P. A., \& Ulupui, I. G. K. A. (2016). Mekanisme Corporate Governance Sebagai Variabel Pemoderasi Pengaruh Pengungkapan Corporate Social Responsibility pada Nilai Perusahaan. E-Jurnal Akuntansi Universitas Udayana, 14(1), 548574.

Ridha, M. ., \& Basuki, H. (2012). Pengaruh Tekanan Eksternal, Ketidakpastian Lingkungan dan komitmen Manajemen terhadap Penerapan TransparansiLaporan Keuangan. Simposium Nasional Akuntansi XV Banjarmasin. 
Scott, W. R., Smith, K. G., \& Hitt, M. A. (2004). Institutional Theory: Contributing to a Theoretical Research Program Institutional Theory: Contributing to a Theoretical Research Program Chapter prepared for Great Minds in Management: The Process of Theory. Great Minds in Management: The Process of Theory Development, January 2005, 460485.

Sholekah, F. W., \& Venusita, L. (2014). Pengaruh Kepemilikan Manajerial, Kepemilikan Institusional, Leverage, Firm Size dan Corporate Social Responsibility terhadap Nilai Perusahaan Pada Perusahaan High Profile Yang Terdaftar di Bursa Efek Indonesia Periode Tahun 2008-2012. Jurnal Ilmu Manajemen, 2(3).

Suastini, N. M., Purbawangsa, I. B. A., \& Rahyuda, H. (2016). Pengaruh Kepemilikan Manejerial dan Pertumbuhan Perusahaan terhadap Nilai Perusahaan Pada Perusahaan Manufaktur Di Bursa Efek Indonesia. E-Jurnal Ekonomi Dan Bisnis Universitas Udayana, 5(1), 143-172. Syafitri, T., Nuzula, N. F., \& Nurlaily, F. (2018). Pengaruh Good Corporate Governance terhadap Nilai Perusahaan (Studi pada Perusahaan Sub Sektor Food and Beverages yang Terdaftar di BEI Tahun 2012-2015). Jurnal Administrasi Bisnis (JAB), 56(1), 49-57.

Sugiyono. 2017. Metode Penelitian Kuantitatif, Kualitatif dan $R \& D$. Bandung: Alfabeta.

Suliyanto. 2011. Ekonometrika Terapan: Teori Dan Aplikasi Dengan SPSS. Edisi 1. Yogyakarta: ANDI Yogyakarta.

\section{PROFIL BIODATA}

Dendi Purnama, lahir di Kuningan Jawa Barat pada tanggal 09 Februari 1990. Menyelesaikan Pendidikan Magister Sains Akuntansi pada Program Studi Akuntansi Tahun 2015. Saat ini beraktifitas sebagai Dosen Tetap di Universitas Kuningan.

Epi Aprianti, lahir di Ciamis Jawa Barat pada tanggal 04 April 1998. Menyelesaikan Pendidikan Sarjana Ekonomi pada Program Studi Akuntansi Tahun 2020.

Enung Nurhayati, lahir di Karawang Jawa Barat pada tanggal 21 September 1977. Menyelesaikan Pendidikan Magister Sains Akuntansi pada Program Studi Akuntansi Tahun 2015. Saat ini beraktifitas sebagai Dosen Tetap di Universitas Kuningan. 